\title{
Geographical cataloguing of earthen architecture in Soria, Spain
}

\author{
I.J. Gil Crespo \\ Universidad Politécnica de Madrid, Spain
}

\begin{abstract}
This paper discusses the most relevant earth construction techniques that have been employed in the province of Soria (Spain). The objectives of the research are, first, to locate and catalogue each earthen building technique, within the geographic regions and environmental units and their relation to physical and human environment. Then, the second aim is to analyze these techniques and characterize them in terms of material, components and construction processes. Three types of earthen construction are studied: rammed-earth walls, adobe masonry and timber frame filled with adobe.
\end{abstract}

\section{GEOGRAPHICAL EXTENSION, AIMS AND METHOD}

\subsection{Geographical extension}

The field of study is the province of Soria, although the administrative frontier does not correspond to the geographical, cultural and, therefore, architectural frontier.

This territory has always been a border region, under the point of view of geography and history. The division between the Duero and Ebro basins crosses through the province. It is, also, the boundary between the Central Plateau and the Depression of the Ebro, and the meeting between the Central and Iberian mountainous Systems. During the Reconquista it was frontier territory between the Christians and the Islamic Caliphate. Later, with the consolidation of the Crowns, it became again a frontier and the border was continuously disputed between Castile and Aragon.

\subsection{Aims}

This research continues the work begun during the doctoral research. The initial research was focused to study the earth construction techniques, in the traditional architecture of the province of Soria (Spain): its constructive reason, its geographical location, its link with the physical, human and architectural environment, its conservation status, the pathological agents and the proposed of conservation criteria from the point of view of environmental and architectural sustainability. This paper develops the second aim: to locate each building techniques with earth and relate it with the geographic region.

\subsection{Method}

The research method was followed, fundamentally, through exhaustive fieldwork by which cartographic, photographic, surveying, construction data, material samples and interviews has been compiled. This fieldwork was complemented with bibliographical work in which the published references were analyzed.

It was developed a complete list of the towns and villages of the province, including the uninhabited that are not reflected in some databases or local listings. In each town a numeric code was assigned. This code identified all other data collected: buildings cards, material samples, photographic documentation, mapping and surveying. It has also developed a computerized base map, on which the physical and human environment was linked with the location of the construction techniques of traditional architecture with earth.

During several days, the researcher collected on site data, exploring several routes. Up to 200 of the 538 towns were visited, comprising major geographical regions with presence of earthen architecture.

For data collection, a standard form was used. On the first page, general data of the building was collected, the architectural type and the location map were specified. The second page of the data collection form contained details of construction systems, specifying its elements and materials. The third page was dedicated to study the damage state. Finally, a fourth page was added with relevant photographic documentation and, if necessary, more pages with other data, such as surveys or details.

Data from more than two hundred buildings was identified. It covered a wide range of building types constructed with the various earthen architecture techniques: rammed-earth walls, adobe masonry and timber frame filled with adobe. 
A series of analytical maps of physical and human resources was designed by using the map base. Maps were developed with the geographic location of each building technique. The comparative method allowed linking them with the environment because the representation of the information was made on the same cartographical basis.

\section{THE PHYSICAL AND HUMAN ENVIRONMENT}

Architecture has a close relationship with the materials founded in the geological environment. In the province of Soria, there is a wide variety of soils and, therefore, building materials.

Morphologically, there are three fundamental areas. On the north and east of the province, there are mountains of the Iberian System. On the south, there is the junction between the Central and Iberian Systems. In the middle are the high plains, between which it is opened the Duero valley. At the Southeast, there is the Jalón valley, a tributary of the Ebro river (Taracena \& Tudela 1968).

In Lithological terms, the soils of Soria are mainly limestone, which were formed in the Secondary Era and part of the Tertiary. They are sedimentary rocks as limestone, sandstone and marls in forms of hills and high plains. These rocks, many of them formed by oceanic deposits are sometimes soft and friable. Clay soils are the most recent. They were formed in the Tertiary and Quaternary Eras and they occupy the basins of main rivers (Tejero de la Cuesta 1988).

In terms of geology, the territory is formed from an old surface of limestone from Miocene strata reworked by karst and fluvial processes. In the Quaternary, the fluvial net is formed with hierarchy and there are a series of ramps and terraces, which dissolved the limestone. Trawls materials are deposited on the valley floor. There is gravel, sand and silt between the sandstone and limestone of the high plains.

The hydrographic network is dominated by the source and the first part of the Duero river. It collects the water of most of the rivers in the province. But both on the northeast and southeast, there are river valleys leading to the Ebro. These rivers and basins had historically articulated the territory and served as natural communication roads (Arenillas Parra \& Sáenz Ridruejo 1987).

It is also important to study the vegetation and its location if it is relevant to link the constructive techniques with the environment. Traditional construction has always taken advantage of the presence and easy availability of wood to make use of it, and it also happened with the presence of cereal growing to get the straw for the adobes. This cereal growing spread, through the west, in the Duero valley, towards Aranda de Duero and the plains of Fuentepinilla; in the north, it is in the valleys of Almarza and Merdancho rivers, the Campillo, the moors of Yanguas and San Pedro Manrique and the plains of Ólvega and Castilruiz; in the south, it is in the valley of Jalón river. Finally, it is in the eastern of the province: Almazán, Campo de Gómara, the and Araviana and Rituerto valleys. The center of the province, where the Duero draws a bow, and the mountains are covered with forest vegetation, while the moors of the south and north-east have a greater presence of bushes (Puy 2007).

Thus, in those towns surrounded by forests, it is easier to the timber-framed walls or rain-walls (tabique-pluvial), while large areas where there is cereal growing, there will profusely be an architecture of adobe or rammed-earth. Here, timber is exclusively used for the horizontal elements, roofs and carpentry.

The analysis of the human environment reveals that the main towns are grouped along Duero and Jalón rivers courses, plus the main towns of Ólvega Ágreda. In these places, and also the Pinares area at northwestern, there were less emigration. Hence, population growth and there was an economic development. Therefore, the architecture evolved and traditional architecture was modified, so that the examples are less original. In small villages and those localities without population, traditional techniques can be studied without alterations, despite the neglect and the ruins.

\section{LOCATION OF EARTH ARCHITECTURE IN THE PROVINCE OF SORIA}

The data collected was taken in more than 200 towns and villages (about half of the total). With this data, a series of maps were drawn to locate the earth-construction techniques in the province of Soria. This documentation consists of multiple cartographic maps, which are summarized published in this paper the most relevant.

The first of them (called AT-0) is the base map of the province without any architectural information: only the administrative division. The second one (AT-1) is a summary of the fieldwork. It identifies the towns in which there is any construction technique with earth. This map draws also those places where the stone is the main construction material. The third (AT-2) selects the presence of rammed-earth, while the timberwork with adobe filler is recorded in the map AT-3. At last, the map AT-4 is the geographical distribution of adobe masonry walls. These maps are in process of complete them yet. 
One of the methods of analysis was through mapping comparison. The physical and human environments were illustrated on the same maps, on which the location of the construction techniques was also identified. The overlap of these maps gives conclusions, such as the overlap of the maps AT-1 and the geological map, by what map AT-1.1 has been drawn. Also, the overlap of the map of the distribution of the cereal growing and the adobe location gives the map AT-3.1, while the overlap of the map of forest and vegetation with the map of the distribution of timberwork with adobe filler gives the map AT-4.1.

The immediate conclusion of the map AT-1.1 is that earth construction is employed only in those places where there are soils of Quaternary land-the basins of the rivers - or conglomerates of sand and clay - in some moors. Earthen architecture is located in the entire Duero valley and the valleys of major rivers such as the Jalón and the Queiles. Also it is in the surrounding moors.

\subsection{Rammed earth walls}

In the plane AT-2, summarized in Figure 2, it can be identified the presence of rammed-earth. This technique has been traditionally used in the centraleastern part of the province, significantly closer to Aragón, south and east of the Duero river; that is: in the regions of Ágreda, Gómara fields, the Vicarías and the basins of Almazán and Jalón. An explanation for this zoning could be that in these regions the Islamic presence was stronger and durable, as following the Reconquista these towns where repopulated with Moors. In these regions, it is also easy to find noble buildings constructed with rammed-earth.

The use of rammed-earth is reduced to the walls of secondary buildings. It is less used, when moving West. In the regions of Vicarías and Ágreda, rammed-earth construction affects a more variety of architectural types: military fortifications, palaces, houses and agricultural buildings. In the region of Almazán and Campos de Gómara, there are many houses in which the use of rammed-earth coexists with other techniques within the same constructive elements. In the Duero valley, its use is limited to the walls of orchards and farmyards, rarely in houses. The rammed-earth technique requires some expertise and auxiliary methods for its building than the adobe masonry. As one moves west along the Duero valley, the technique of rammed-earth is becoming more rudimentary and constructively, more incorrect.

In Soria architecture, the rammed-earth is a technique that by itself does not appear to form

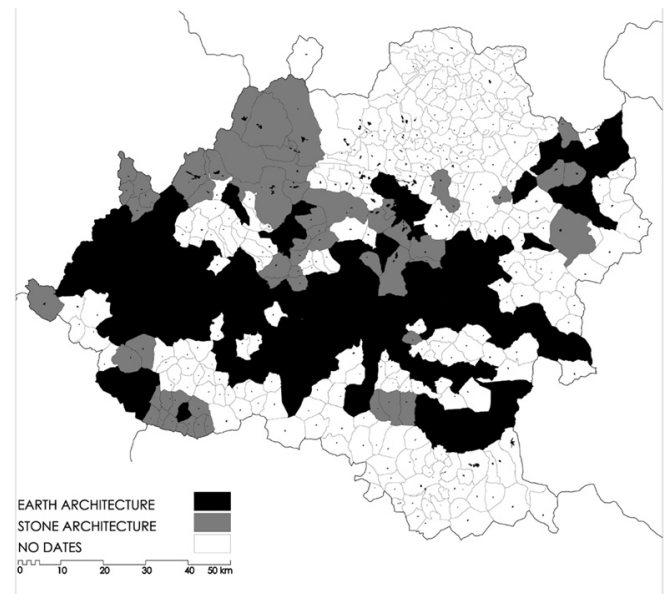

Figure 1. Geographical location of earth and stone architectures in the province of Soria. (Credits: Gil Crespo).

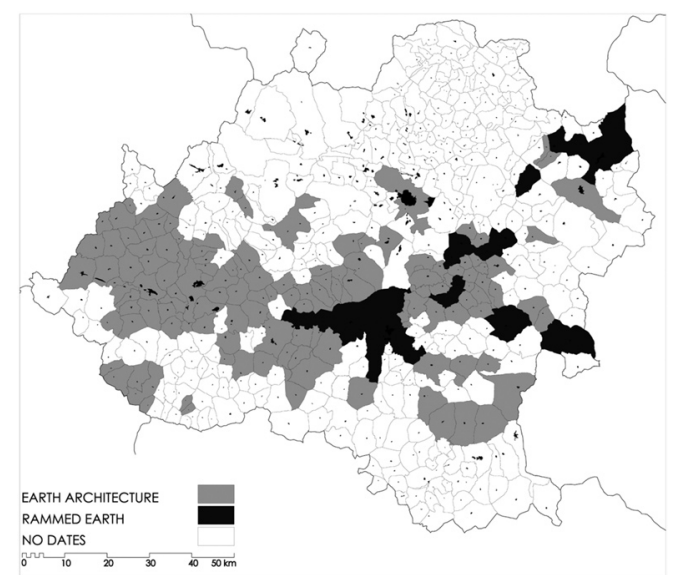

Figure 2. Rammed-earth construction location in the province of Soria. (Credits: Gil Crespo).

constructive elements, but it is always accompanied by other materials, as adobe or stone, in the studied cases. Rammed-earth is used as filler in the faces of the walls, being avoided in the corners and the fragile elements, not solving slopes.

There are some nobility dwellings built with rammed-earth, as is the case of the Palace of the Dukes of La Serna in Castilruiz. It has also been used in fortification as the castles of Yanguas and Serón de Nágima (Gil Crespo 2012). In other castles, it appears as filler of walls. This is the case of Caracena, Ágreda, La Raya and Arcos de Jalón (Gil Crespo 2011). 


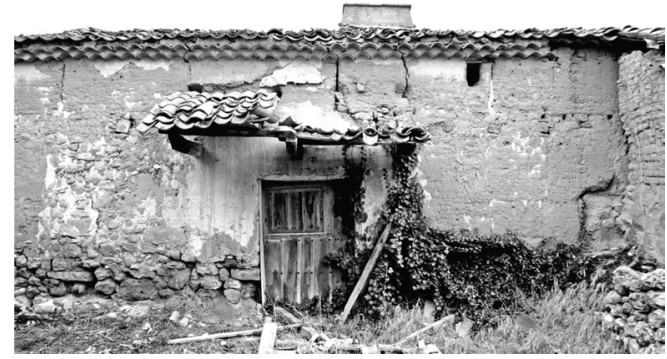

Figure 3. Rammed-earth wall in Covarrubias, with plinth of stone and parts with adobe. (Credits: Gil Crespo).

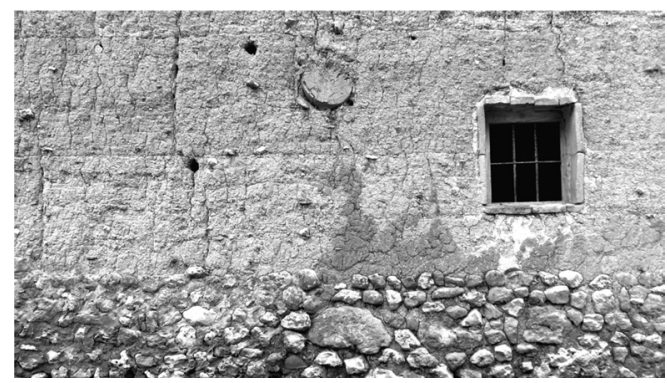

Figure 4. Rammed-earth wall in Almántiga. The window hole is made with bricks as formwork. (Credits: Gil Crespo).

\subsection{Adobe masonry}

The plane of figure 5 (map AT-3.1) shows the geographical location of the adobe masonry overlapped with the cereal growing distribution. The buildings have usually been built with the walls of the first floor in stone. As it is observed in the map, this technique is distributed throughout the province because the adobe masonry is a versatile technique and it is also combined with rammed-earth and timber framework with filler of adobe. The link between the adobe existence and the cereal growing is clear: adobe is made with a mixture of clay and straw and that straw have to be harvested from nearby crops.

Heterogeneity was observed between the adobes of the different regions, mainly due to the diversity of the raw material: the clayish earth that is molded. The straw quantity also varies, even on the adobes of the same wall, which may belong to different periods. The adobes used in the places located in the valleys of main rivers, in which the soil is formed by trawling materials and sedimentation, are composed of reddish clay. By contrast, in the higher parts corresponding to the edges of moorland, clay has greater sand content due to the degradation from limestone. For this reason, the

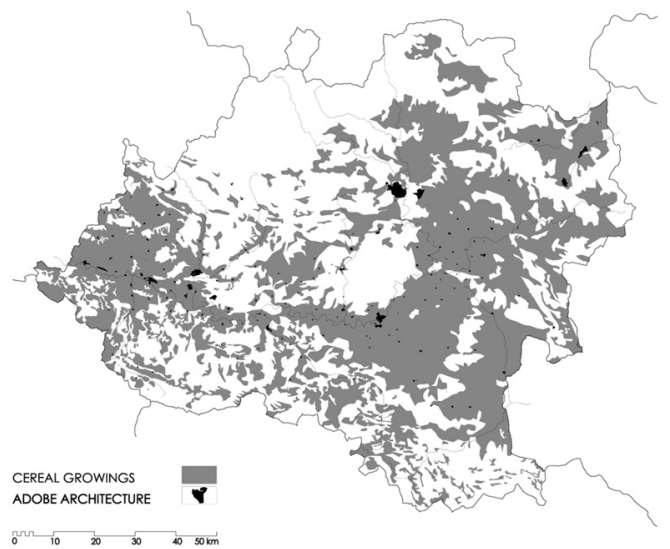

Figure 5. Cereal growing map and location of the towns, where there is adobe architecture. (Credits: Gil Crespo).

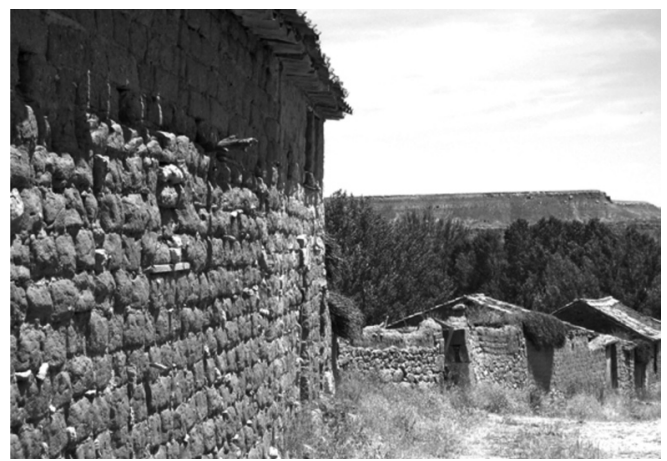

Figure 6. Adobe walls in Peñalba de San Esteban, Spain. (Credits: Gil Crespo).

adobe pieces have whitish tone. Somewhere, the clay has more stones in the mass and this characteristic is also shown then in the adobe.

During data collection, dimensional data of the adobes were collected. There are three types of dimensions. The first of them are bricks whose dimensions are about $20 \times 40 \mathrm{~cm}$ and have a thickness of $11 \mathrm{~cm}$. They are used in masonry one-footwide walls coupled with adobes perpendicular to the wall face and also in half-foot-wide walls. The dimensions of the second type of adobes are around $16 / 17 \times 32 / 34 \mathrm{~cm}$. They are typically used in walls that have alternating adobe rows of parallels or perpendiculars. Finally, there is a third type of adobes, quite distinguishable. They are constituted by smaller and thinner pieces $-14 \times 27 \mathrm{~cm}-$, which have been used mainly in the fillings of the timber framework and on partition walls. No zoning has been noted regarding dimensional types. 
The two most common structural systems in adobe masonry are the one-foot-wide walls coupled perpendicularly to the wall and those that are alternating rows parallels and perpendiculars. Due to dimensional motives, on the corner there are gaps that are filled with rubble and clay. In both cases, significantly 1:1:2 ratio between the sides of the adobe causes the vertical joints to not be securely locked or alternate. This is one of the weaknesses of adobe masonry. There is no system preference according to the region.

The corners are not always rigged with adobe pieces. In many cases, they are made from stone blocks in form of a zipper to define and reinforce the corner. In these cases the low face and the fronts are flattened, but not the face that is in contact with the adobe wall. To arrange an encounter between the two materials, the adobes are cut and sometimes their constructive direction is changed. The holes between the adobe and the corner stones are filled with gravel and clay.

\subsection{Timber framework with adobe filler}

Figure 5 is the map AT-4 in which it is drawn the places where there are buildings with timber framework with adobe refill. This technique has been developed in the western regions. There is not scarcely overlap with the area that there is rammedearth construction. Indeed, timber framework takes place in the Castilian region of the province, while the rammed-earth has been used more in the Aragonese border.

When compared cartographically, the distribution of vegetation in the province, with the presence of timber framework construction, it can be seen that there is two conditions to this technique. First, there must be near forest areas for the timber and, second, there must be clay in the soil for the adobe, which will be used as filler between the struts and other timber elements.

The difference between timber-reinforced walls and timber framework is that, in the first of them, the supporting element of the wall is the adobe factory, which is reinforced with timber elements that provide stability to the masonry. The timber framework is stable by itself, while the adobe masonry is only filler. The dimensions of the wooden struts in the reinforced walls are larger than in the framework. The separation between these struts is usually around 80 to $100 \mathrm{~cm}$, so that it is filled with two or three adobes. This separation is smaller in the timber framework.

This construction system uses the earth, in adobe shape, as filler. Originally adobe filling has no structural function in the timber framework, but over time become a solidary structure with the timber. The adobe filler is often rigged in form of

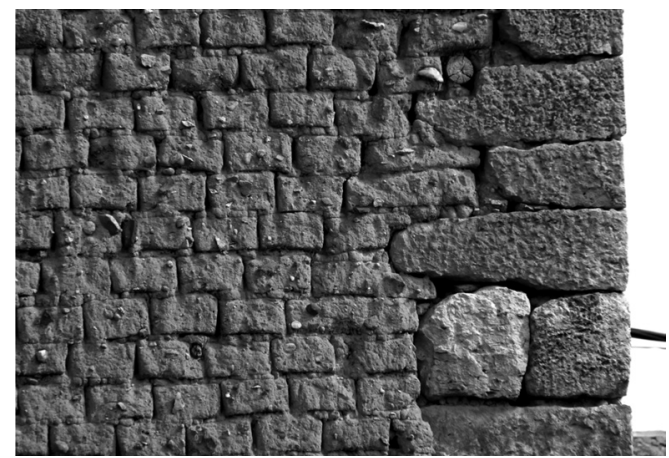

Figure 7. Stone corner in Caltojar. (Credits: Gil Crespo).

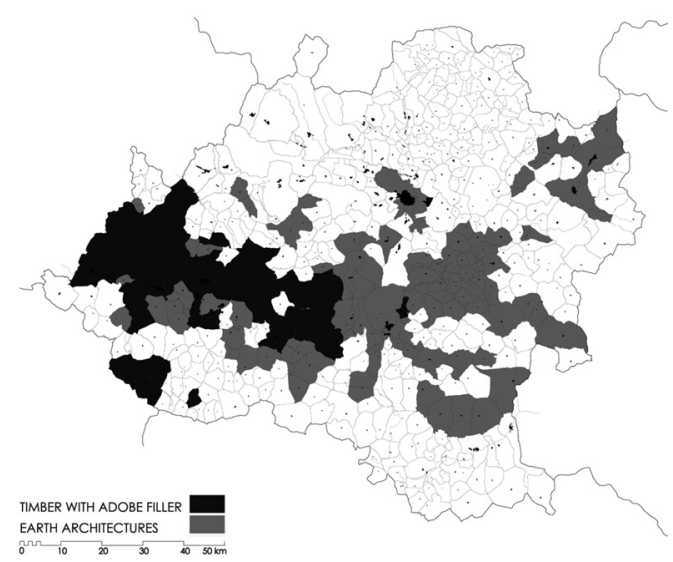

Figure 8. Timber framework with filler of adobe distribution in the province of Soria, over the map of forests. (Credits: Gil Crespo).

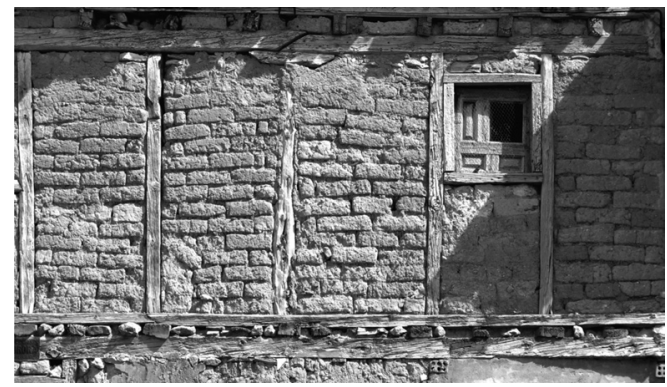

Figure 9. Timber reinforced wall in Zayas de Bascones. (Credits: Gil Crespo).

fishbone - sloping between two struts - or, if there is more space, directly as adobe masonry in horizontal ropes. In any case, the whole structure is covered and protected by the coating.

The woods that have been used are those of juniper (Juniperus Thurifera) and, lesser degree, 


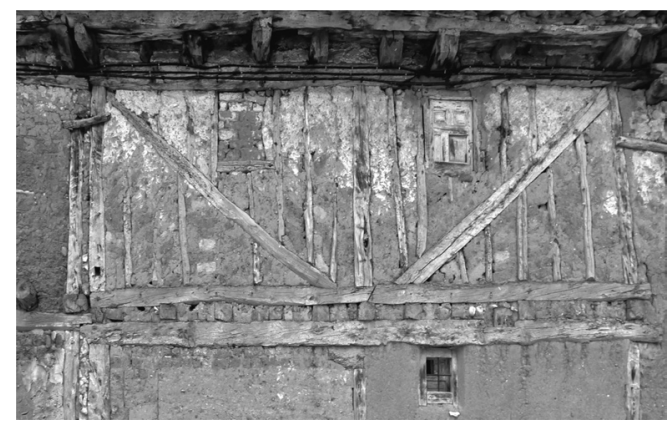

Figure 10. Timber framework in Valdenebro. (Credits: Gil Crespo).

pines (Pinus Sylvestris, Pinus Nigra), and poplar trees (Populus Alba, Populus Nigra). The timber is flatted and cutted depending on its structural function. This aspect shows an elementary but effective structural knowledge.

\section{CONCLUSIONS}

There is a clear zoning of constructive techniques with earth. On the one hand, there are natural reasons such as the presence of materials - earth, stone, wood, straw-dependent on the physical environment: lithology, vegetation, etc. On the other hand, there are historical reasons: the natural division between the Duero and Ebro valleys-between Castile and Aragon - is also an human limit and it is shown as such on the use of rammed-earth.

Rammed-earth has been employed on castles and unique buildings, while the adobe does not. Rammed-earth requires more knowledge and tools, as well as it has a higher surface resistance due to an external harder lime crust, commonly known as calicastrado. Rammed-earth, however, is rarely used as the only building material for all of the building. It is completed with the use of adobe and stone finishes for the head of the walls and the singular points as the corners.

In adobe masonry it has been observed that the different sizes of pieces have different functions. Smaller pieces are used to the filler of the timber framework, while the bigger ones are employed in the masonry walls.

The use of frames was frequent in those areas where there were predominantly forests. In this case, the presence of earth was, in origin, a simple filler with no structural function: hence the nonchalance in the rigging of adobe filler between the struts. Over time, it has been observed that it acquires structural function due to the failures and injuries in the timber structure and that this neglect accelerates disease processes.

Last, this research is not concluded yet, as maps of the whole province are under development, offering a complete catalogue of the earthen construction techniques in the province of Soria.

\section{ACKNOWLEDGEMENTS}

The $\mathrm{PhD}$ research work was directed by Prof. $\mathrm{Ph}$. D. Luis Maldonado Ramos, from the Construction Department of the School of Architecture of Madrid, Spain.

\section{REFERENCES}

Arenillas Parra, M. \& Sáenz Ridruejo, C. 1987. Guía Física de España 3, Los Ríos. Madrid: Alianza Editorial.

Gil Crespo, I.J. 2010. Fundamentos constructivos y análisis patológico de la arquitectura de tierra en la provincia de Soria. Research work directed by Luis Maldonado Ramos. Universidad Politécnica de Madrid

Gil Crespo, I.J. 2011. Fundamentos constructivos de las fortificaciones bajomedievales en la provincia de Soria: fábrica de mampostería con verdugadas de ladrillo en el castillo de Arcos de Jalón. In Huerta, Santiago \& Gil Crespo, Ignacio Javier \& García Suárez, Santiago \& Taín Guzmán, Miguel (eds.), Actas del Séptimo Congreso Nacional de Historia de la Construcción, Santiago de Compostela 26-29 de octubre de 2011. Madrid: Instituto Juan de Herrera

Gil Crespo, I.J. 2012. Rammed earth walls in Serón de Nágima castle (Soria, Spain): constructive lecture. In C. Mileto, F. Vegas, V. Cristini (eds.), Rammed Earth Conservation. Londres: Taylor \& Francis.

Gil Crespo, I.J. 2012. Estudios previos para el análisis constructivo y catalogación geográfica de la arquitectura de tierra en la provincia de Soria. Celtiberia 106: 523-556

Hoz Onrubia, J. \& Maldonado Ramos, L. \& Vela Cossío, F. 2003. Diccionario de construcción tradicional. Tierra. San Sebastián: Nerea.

Maldonado Ramos, L. 2009. La construcción con tierra. In H. Martín \& A. Eduardo (ed.), Tratado TécnicoJurídico de la edificación y del urbanismo. Pamplona: Aranzadi.

Puy, J.P. (ed.) 2007. Encuentro de paisajes. Directrices de ordenación de la provincia de Soria. Salamanca: Consejería de Fomento \& Junta de Castilla y León

Taracena, B. \& Tudela, J. [1928] 1968. Guia artística de Soria y su provincia. Madrid: Esograf.

Tejero de la Cuesta, J.M. (ed.) 1988. Análisis del medio fisico. Provincia de Soria. Valladolid: Junta de Castilla y León, Consejería de Fomento. 